\title{
Developing the Students' Ability in Understanding Mathematics and Self-confidence with VBA for Excel
}

\author{
Martin Bernard ${ }^{1}$, Eka Senjayawati $^{1}$ \\ ${ }^{1)}$ Department of Mathematics Education, IKIP Siliwangi, Cimahi \\ Corresponding author: pamartin23mard@,gmail.com
}

\begin{abstract}
Visual Basic Application for Excel is a simple program language and has the power to process data quickly. The utilization of math functions in Microsoft Excel can belp work on Excel display more interactive so that teachers can create props inside Excel. The advantages of Microsoft Excel than other mathematical software are the many math functions and images available in the form of shapes or pictures. The availability of $V B A$, math and image functions in Microsoft Excel help teachers to design the creation of media related to mathematics learning, especially to develop the ability of junior high school students who have difficulty to connect mathematics lessons with basic mathematics knowledge requirements. By using VBA for Excel, the ability of junior high school students to improve in the usual way significantly with a t-test with $0.006<0.05$. Furthermore, there is an association between the students' self-confidence and their mathematical comprehension skills with a contingency coefficient of 0.525 including a moderate association.
\end{abstract}

Keywords:VBA for Excel, Excel Microsoft, ability to understand, self-confidence

Received: $2^{\text {nd }}$ July 2018; Revised: 16 ${ }^{\text {th }}$ November 2018; Accepted: 17thJanuary 2019

\section{Introduction}

Mathematics is one of the essential foundations so that the subjects are taught from an early age to college. It can not be denied that all circles much need mathematics without being limited by age. Through mathematics, a human being can develop logical, analytical, systematic, critical, and creative thinking skills, as well as cooperative abilities applied in daily inhalation (Bernard, 2015:198). Unfortunately, many obstacles faced by students facing math problems. One of them is the lack of pre-requisite understanding that they should be able to master. Their tendency depends on the way the work process should be followed without understanding the actual storyline. The math subjects in the school cause this factor are monotonous and less varied in the use of instructional media, thus fewer interest students (Bernard, 2014:425).

One that must be mastered by students as the key is to learn the concept of arithmetic operations such as sum, subtraction, multiplication, and division. Or associate the mathematical functions that the student thinks are new material but which have actually been studied previously. So the difficulties of students not yet understand the mathematics to the next stage because it has not been able to associate the basic 
mathematics or the so-called prerequisites, this is in accordance with Astuti (2018:69) that students in Indonesia are not accustomed to solving problems.

Another student's difficulty is conveying mathematical symbols and identifying to distinguish symbols such as understanding about variable differences and constants.In fact, the linkage of this concept has been studied as to the set or may be analogous to other forms. Of course, this is needed by the media visually so that students understand some examples. Benefits of mathematics learning media are petrified students who are a concrete operational phase in understanding the material that is abstract or less able to be explained by using verbal language (Batubara, 2017:15).Media to be created must be in accordance with the achievement of mathematics subjects are being studied in the classroom.

To create mathematical media, it should be designed according to the learning strategy about the effectiveness of time, space, and materials. Because it is not easy, media can be made with a short, but not necessarily be useful for students, but the purpose of media provides convenience to students to understand the material so that during the process of mathematics, students are not dependent on the source text (Wijayanti \& Khikmiyah, 2016). Based on the utilization and the purpose of the media, that ICT is a technology that can be used as an alternative media. Because ICT already provides images of various shapes and sizes so easily designed well. One of ICT-based media is Microsoft Excel, and the software is rich in mathematical functions for data processing. Microsoft Excel also provides images such as Shapes, Picture, Graphics, and Diagrams, but at this time most people still connect the data processing cells with graphics such as running Shapes, Picture, Graphs, and Diagrams into a dynamic form by using Visual Basic Application for Microsoft Excel.

According to Chotimah, Bernard, \& Wulandari (2018:4) that Visual Basic Application can create drawings that are designed into a more interactive mathematical tool, and also do not have to cost, and do not need much consideration to choose the material. And even the Visual Basic Application language has a language structure that is not so difficult for high school students or teachers.

The ease of Microsoft Excel software by using VBA, giving students the ability to compile or process understanding to make structured steps that help students misunderstand how the process comes to the results. During this time, the weakness of students is to interpret the symbols of mathematical variables, constants and equations. This is in line with Senjayawati \& Bernard (2018:66) that mathematical software can also solve theorems or mathematical definitions by writing to the results of the objectives.

\section{Research Methods}

The study was conducted in one of the junior high schools in the city of Cimahi, West Java, Indonesia. The samples in this research are two classes with 30 students in the first class and 33 students in the second class. The first class was implemented VBAbased mathematics learning games for Microsoft Excel as an experimental class and the second class was conducted with conventional learning as control class. The research design method with Quasi-Experiments where the selection phase is not done randomly because the two classes selected have the same ability. The research design is as follows.

\section{$\mathrm{O} \times \mathrm{O}$}

\section{O O}


Note:

O: Pretest/Posttest of Understanding Mathematics Ability

$\mathrm{X}$ : Using VBA-Based Games for Microsoft Excel

---------: Non-random samples with the ability of two classes that have the same ability

\section{Results and Discussion}

At the time of pretest, the experimental class and control class are given about the ability to understand the equation of one variable, and the results obtained from both groups in Table 1.

Table 1. Average Value and Standard deviation When Pretest

\begin{tabular}{cccc}
\hline No & Class & Average & Standard Deviation \\
\hline 1 & Experiments & 7.08 & 1.73 \\
2 & Controls & 7.48 & 1.84 \\
\hline
\end{tabular}

Table 1 shows that the average value for the experiment class is 7.08 and for control class is 7.48.This means the control class is higher than the experimental class. And based on the standard deviation aspect, the experiment class is on 1.73 while the control class is on 1.84 which means the standard deviation of experiment class is smaller than the control class, it means that the value of spreading of experiment class data more evenly than control class. For whether there is a difference in the mean of between experimental class and control class, the first step is whether the two grades of students of the course are normally distributed or not.

Table 2. Normal Test of Pretest

\begin{tabular}{llrrrrrr}
\hline \multirow{2}{*}{ Class } & \multicolumn{2}{c}{ Kolmogorov-Smirnov $^{\mathrm{a}}$} & \multicolumn{3}{c}{ Shapiro-Wilk } \\
& Statistic & df & \multicolumn{1}{c}{ Sig. } & \multicolumn{1}{c}{ Statistic } & \multicolumn{1}{c}{ df } & \multicolumn{1}{c}{ Sig. } \\
\hline Value & Control Class & .139 & 29 & .157 & .922 & 29 & .034 \\
& Class Experiment & .147 & 32 & .078 & .955 & 32 & .196 \\
\hline
\end{tabular}

a. Lilliefors Significance Correction

In Table 2, shows the results of statistical values for the controlclass of 0.139 , the degree of freedom is 29 and a significant value is 0.157 . For the experimental class, a result of statistic value is 0.147 with a degree of freedom is 32 and a significant value is 0.78 . Since the significance level of the table is 0.05 then the two significant values for the control and experimental classes are greater than 0.05 . This means that the two data are normally distributed. The homogeneous test will be continued to see whether the dispersion of values a gainst the mean is the same or not. 
Table 3. Test of Mean Differences of Experiment Class and Control when Pretest

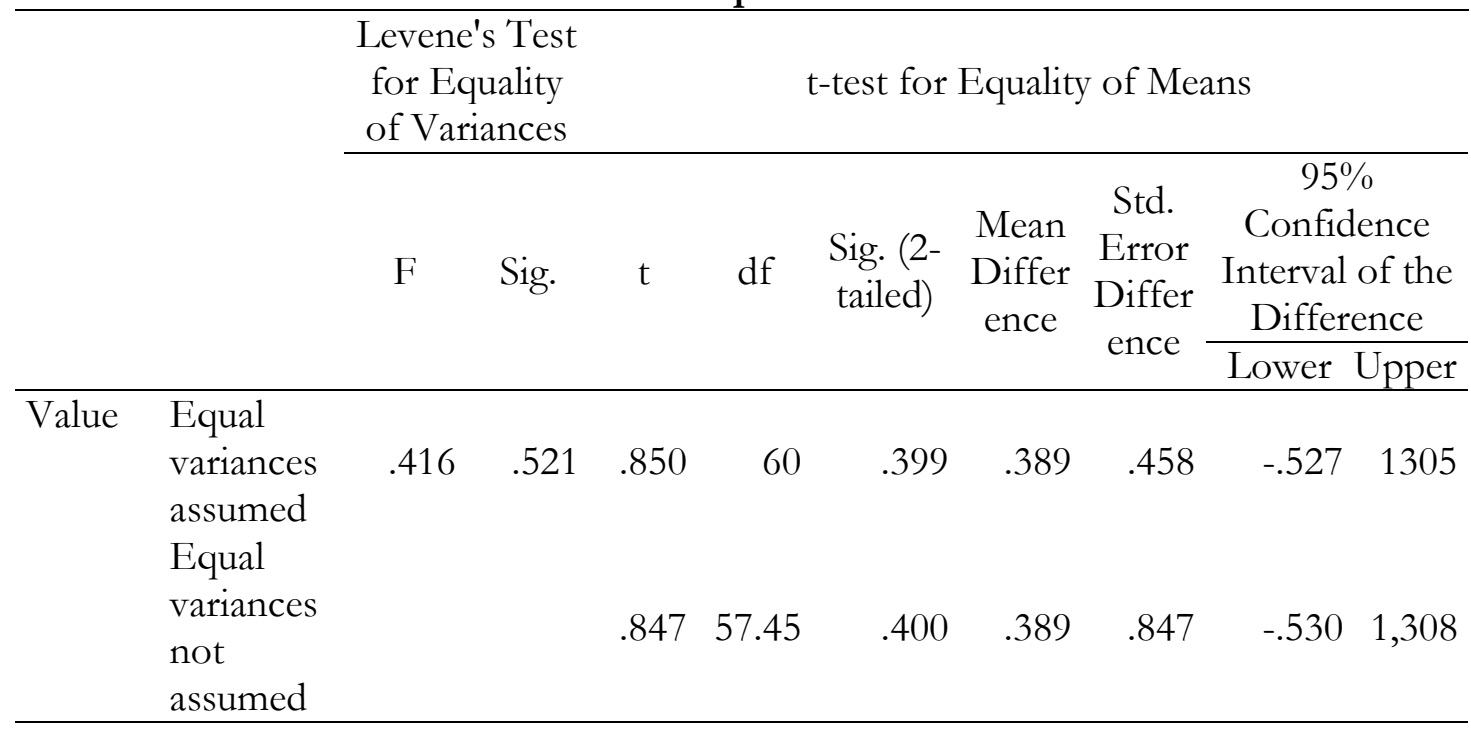

Table 3 shows that the value of the second $F$ test of the data is 0.461 and the significant value of 0.521 is greater than 0.05 , meaning that the two data are homogeneous. To see the average difference between the two groups, taken from the t-test on the data having the same variance of 0.85 with the degrees of freedom 60 and the significant 2 -tailed value of 0.399 . This means that the two average values are not different.

Table 4. Average Value and Standard Deviation At Postest

\begin{tabular}{cccc}
\hline No & Class & Average & Standard Deviation \\
\hline 1 & Experiments & 17.19 & 1.91 \\
2 & Controls & 16.03 & 1.56 \\
\hline
\end{tabular}

Table 4 shows the students' average score at postest for the experimental class is 17.19 , and the average score for the control class is 16.03 means that the average value of the experimental level is greater than the average value of the control class. For the standard deviation value for the experimental class is 1.91 and for the control class is 1.56. Since the control class' standard value smaller than the experimental level, then the scores of the students' grade of control on the average value are more evenly than the experimental class. And to see the average difference between the two classes, both data must normally be tested.

Table 5. Normality Test at Postest

\begin{tabular}{llrrrrrr}
\hline \multirow{2}{*}{ Class } & \multicolumn{3}{c}{ Kolmogorov-Smirnov $^{\mathrm{a}}$} & \multicolumn{3}{c}{ Shapiro-Wilk } \\
\cline { 2 - 8 } & Statistic & $\mathrm{df}$ & \multicolumn{1}{c}{ Sig. } & Statistic & df & Sig. \\
\hline Value & ClassControl & .158 & 29 & .054 & .956 & 30 & .249 \\
& Experiment Class & .148 & 32 & .071 & .970 & 32 & .512 \\
\hline
\end{tabular}

a. Lilliefors Significance Correction

In Table 5, the statistical value used Kolmogorov-Smirnov for control class is 0.1458 , degrees of freedom is 32 and a significant value is 0.071 . For control class statistic value is 0.158 , degrees of freedom is 29 and the significantvalueis 0.054 . Since both data 
have a significant value greater than 0.05 , then both data are at the normal distribution and continued with the homogeneous test.

Table 6. Test of Mean Differences of Both Classes When Postets

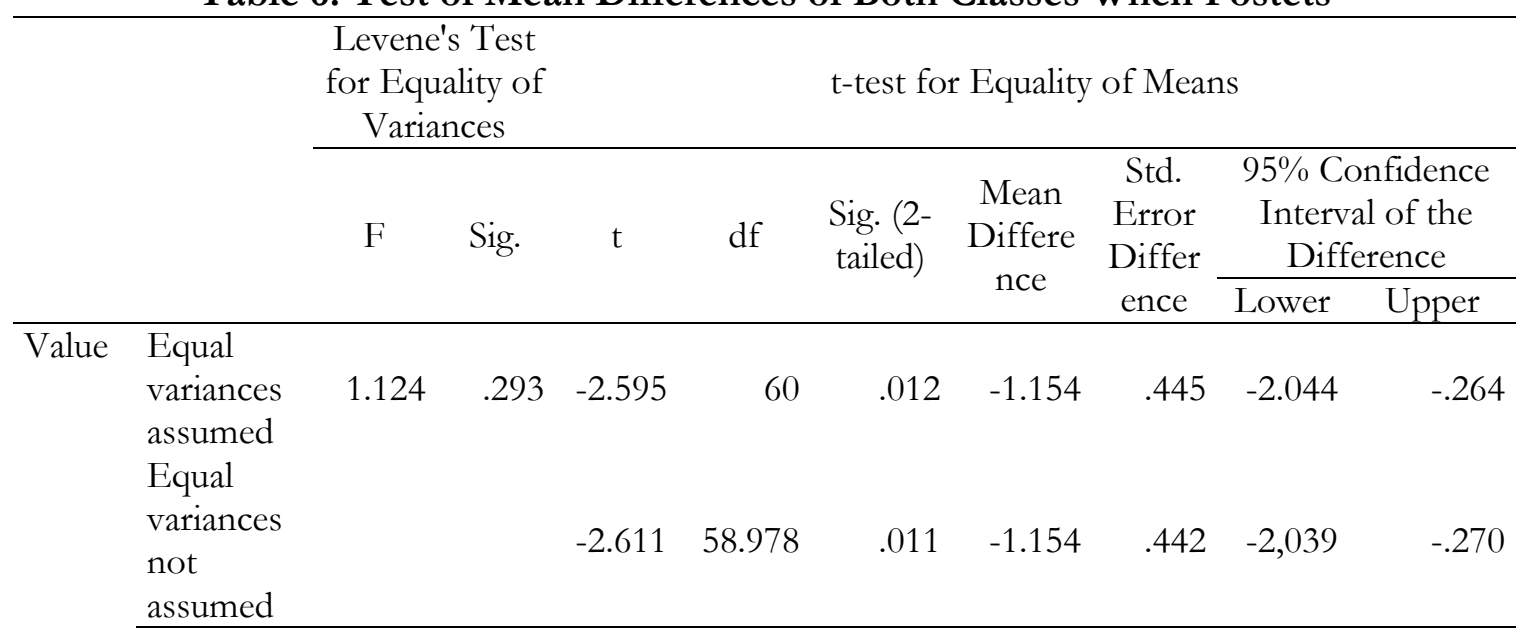

Table 6 shows that the F-test for both data is 1.124 with significant value is 0.293 bigger than 0.05 . This means that both information is homogeneous, then continued with the analysis of difference of average that is t-test and got value -2.59 , the degree of freedom is 60 and significant value is 0.012 for 2 -tailed. While for the 1-tailed to see that which grade is better, then the considerable value is divided into 2 into 0.006 Uyanto (2009:153) less than 0.05 , and according to table 4 that the average value of the experiment larger than the control class then the experimental level is better than the control class.

To see if there is an increase in pretest or early learning with post-learning then the $\mathrm{N}-$ Gain seen on each student based on table 1 and Table 4 shows that both classes show an increase in mean value, then compare which is better $\mathrm{N}$ - gain between two levels.

Table 7. Average Value and Standard Deviation N-Gain

\begin{tabular}{cccc}
\hline No & Class & Average & Standard Deviation \\
\hline 1 & Experiments & 0.77 & 0.24 \\
2 & Controls & 0.68 & 0.16 \\
\hline
\end{tabular}

In Table 7 , that the average value of $\mathrm{N}$-gain in the class the experiments were larger than the average $\mathrm{N}$-gain values in the control class, and the standard deviation value of $\mathrm{N}$-gain of the control class was smaller than that of the experimental $\mathrm{N}$-gain class, meaning that the control group's N-gain values were more evenly distributed than the experimental level. To see the difference in the average of the two classes especially for the normality test of the two data.

Table 8. N-Gain Normality Test

\begin{tabular}{|c|c|c|c|c|c|c|c|}
\hline \multirow{2}{*}{\multicolumn{2}{|c|}{ Class }} & \multicolumn{3}{|c|}{ Kolmogorov-Smirnov $^{a}$} & \multicolumn{3}{|c|}{ Shapiro-Wilk } \\
\hline & & Statistic & df & Sig. & Statistic & $\mathrm{df}$ & Sig. \\
\hline \multirow[t]{2}{*}{ Value } & ClassControl & .107 & 29 & $.200^{*}$ & .980 & 30 & .837 \\
\hline & Experiment Class & .112 & 31 & $.200^{*}$ & .955 & 32 & .200 \\
\hline
\end{tabular}

a. Lilliefors Significance Correction 
In Table 8, it shows that the statistical value using Kolmogorov-Smirnov for the experimental class is 0.112 and the control class is 0.107 with each degree of freedom is 29 and 32 respectively. The significant value of for both data is 0.200 greater than 0.05.This meanis that the two data are typically distributed. And continued with a homogeneous test.

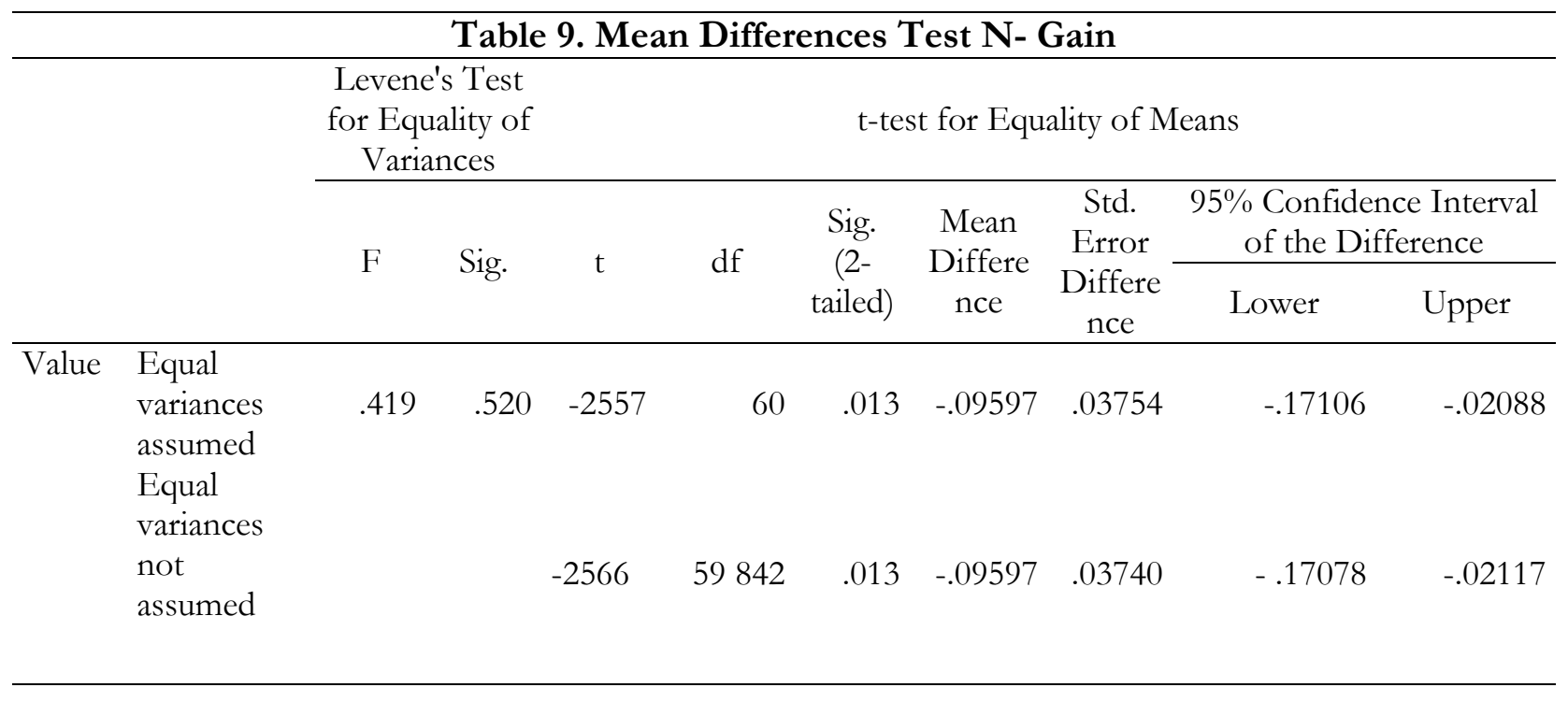

Table 9, shows the F test value of both data is 0.419 and its significant value is 0.52 greater than 0.05 . This means that the two average values of $\mathrm{N}$-gain are homogeneous, followed by the test of average difference with using t-test, with $t-2.557$ value, degree of freedom is 60 and significant value of 2-tailed 0.013 , to see t-tailed test result hence substantial result of t 2 -tailed t-test divided by equal to 0.0065 smaller than 0.05 means that the average value of $\mathrm{N}$-gain experiment better than the control class.

The ability of students understanding mathematics by using VBA-assisted math games for Microsoft Excel is presented in Table 10.

Table 10. Association of Student Math Ability to Student Understanding

\begin{tabular}{llrrrr}
\hline & \multicolumn{4}{c}{ Ability of Mathematics } & \\
& Low & Medium & High & \multicolumn{2}{c}{ Total } \\
\hline Underst Low & 1 & 3 & 2 & 6 \\
anding & Medium & 6 & 11 & 5 & 22 \\
Ability & High & 0 & 4 & 0 & 4 \\
\hline Total & 7 & 18 & 7 & 32 \\
\hline
\end{tabular}

In the table, it explains that there is 1 student who has low mathematics ability is also low on the strength of understanding. There are 3 students of moderate math skills but low comprehension ability, 2 students with high ability in mathematics but low comprehension ability, 6 students with low ability of math but their ability of understanding, 11 students that ability of math and the mathematical knowledge of the agreement is also low, 5 students with high math ability but medium understanding ability, 4 students of medium math ability but high understanding ability. Those mean that there is an increase of $85 \%$ of students have low capacity to have a moderate value, there is a decrease of $16.67 \%$ average ability of math has low comprehension ability, but an increase of $22.22 \%$ math ability has a high understanding ability. While high math 
ability $71.43 \%$ decline in the ability to moderate and $28.57 \%$ comprehension ability to lower the 20 highest value and lowest value 13 .

Table 11. Value of Chi Square forAssociation.

\begin{tabular}{lccr}
\hline & Value & df & $\begin{array}{c}\text { Asymp Sig. } \\
(2 \text {-sided })\end{array}$ \\
\hline Pearson Chi-Square & $4.040^{\mathrm{a}}$ & 4 & .401 \\
$\begin{array}{l}\text { Likelihood Ratio } \\
\text { Linear-by-Linear }\end{array}$ & 5,475 & 4 & .242 \\
$\begin{array}{l}\text { Association } \\
\text { N of Valid Cases }\end{array}$ & .224 & 1 & .636 \\
\hline $\begin{array}{l}\text { a. } 8 \text { cells }(88.9 \%) \text { have expected count less than 5. The minimum } \\
\text { expected count is .88. }\end{array}$ & 32 & & \\
\end{tabular}

Table 11 explains the value of Chi Squares 4.04 with degree of freedom is 4 and a significant value of 0.401 greater than 0.05 . This means that there is no association between mathematical ability and students' comprehension abilities.

\begin{tabular}{llcccc}
\multicolumn{2}{c}{ Table 12. Association of Student Self Confidence } \\
Questionnaire with & Understanding Skill Student \\
\cline { 3 - 5 } & & \multicolumn{3}{c}{ Questionnaire } & \\
\cline { 2 - 4 } Value & Low & Medium & High & Total \\
\cline { 2 - 4 } & Low & 1 & 3 & 1 & 5 \\
& Medium & 5 & 16 & 1 & 22 \\
& High & 0 & 1 & 4 & 5 \\
\hline Total & 6 & 20 & 6 & 32 \\
\hline
\end{tabular}

The Table 12 explains that there is 1 student with low and low ability understanding. There are 3 students with moderate questionnaire but have a low score, 2 students with high questionnaire but low comprehension ability, 5 students with low questionnaire but have medium understanding ability, 16 students have a medium questionnaire and have medium ability, a student with high questionnaire but medium understanding ability, a student with a medium questionnaire, and 4 students with high questionnaire and high comprehension ability. Consistently $16.67 \%$ of students with low questionnaires and low comprehension skills, $80 \%$ of students with medium questionnaires and medium comprehension skills and 50\% of students with high questionnaires and high comprehension skills.

Table 13. Contingency Questionnaire and Student Understanding Understanding

\begin{tabular}{|c|c|c|c|c|c|}
\hline & & Value & $\begin{array}{c}\text { Asymp. Std. } \\
\text { Error }^{\mathrm{a}}\end{array}$ & Approx. $\mathbf{T}^{\mathrm{b}}$ & Approx. Sig. \\
\hline \multirow{4}{*}{$\begin{array}{l}\text { Nominal by } \\
\text { Nominal } \\
\text { Ordinalby Ordinal }\end{array}$} & Contingency & 016 & & & 525 \\
\hline & Coefficient & 010 & & & $.3 \angle 3$ \\
\hline & Gamma & .255 & .335 & .729 & .466 \\
\hline & $\begin{array}{l}\text { Spearman } \\
\text { Correlation }\end{array}$ & .169 & .229 & .940 & $.355^{\mathrm{c}}$ \\
\hline interval by interval & Pearson's R & .184 & .214 & 1.024 & $.314^{\mathrm{c}}$ \\
\hline $\mathrm{N}$ of Valid Cases & & 32 & & & \\
\hline
\end{tabular}


Table 13 informs the contingency value of the association between students 'selfconfidence questionnaires. Students' comprehension ability is obtained with a value of 0.525 and considered as a moderate category and for its significant value is 0.016 less than 0.05 . This means that there is an association between students 'self-confidence and students' understanding ability.

Students have difficulty at the beginning of learning to determine the value of $\mathrm{x}$ from the concept in two segments. Introduction students from grade 7 have not mastered the basic math prerequisites, namely students have not been able to share concepts, the properties of addition and multiplication operations such as commutative, distribution, identity, inverse and distribution. This causes knowledge about mathematics education (Jarlskog, 2016:50). Students who have not been able to interpret the operations of counting mathematics, other than that other factors of mathematical concepts and difficulties in drawing and calculating operations (S. Chamundeswari, 2014:34)

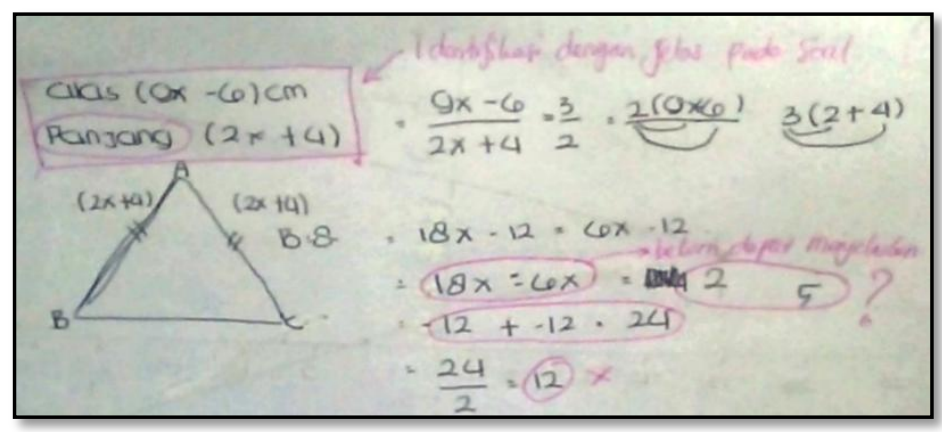

Figure 1. Student Difficulties in the Counting Process

In Figure 1, the first grade of junior high school student's work shows mistake.In the beginning, it is not appropriate to adjust the problem and the picture. Secondly, the multiplier counting process is correct but when the method determines the value of $\mathrm{x}$, the student begins to get confused, seen when the student moves the 6x amount from the right and the left, as well as the number of the -12 from left to right, and the end result is less precise.

From the observations of 32 students, according to the mathematical calculation process shows that of $10.64 \%$ miscalculation of students with the nature of distribution, $54.37 \%$ of students' errors in the concept of comparison, $68.53 \%$ of errors made the number and operation of calculations with property identity, and $67.95 \%$ of students have not been able to connect between images and mathematical concepts. This is in line with Njagi (2015:169) student difficulties because of the weak ability to understand mathematical symbols, this can be seen in the results of the workmanship, the student's error identifies the symbol link - mathematical symbols with pictures.

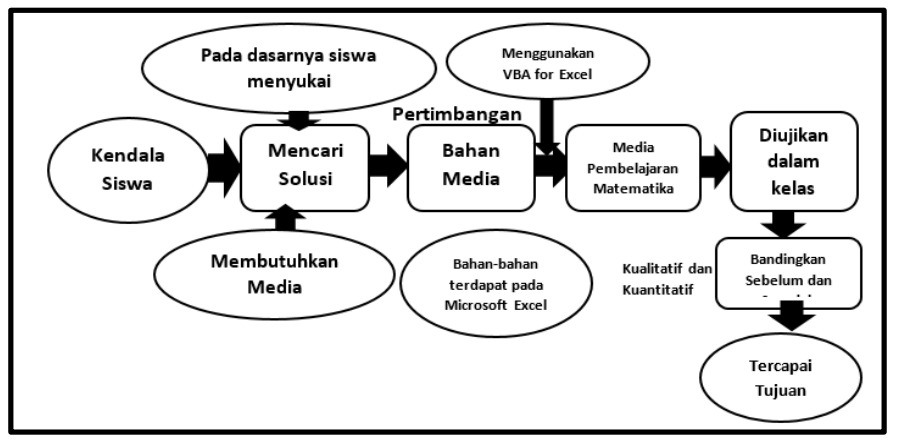

Figure 2. Mathematics Game Design Game 
In the first step, the researchers collected data from 32 students for consideration. The second step of the researchers created a solution that could connect between mathematical concepts and learning media according to the cost and time of manufacture. Judging from its utilization, the mathematics learning media using Microsoft Excel based on VBA is more practical and efficient, because the software already provides images with various shapes and sizes taken from Shapes in the Insert menu and its advantages, it is easy to process numbers related to images to make more interactive math game (Bernard \& Chotimah, 2018:2).
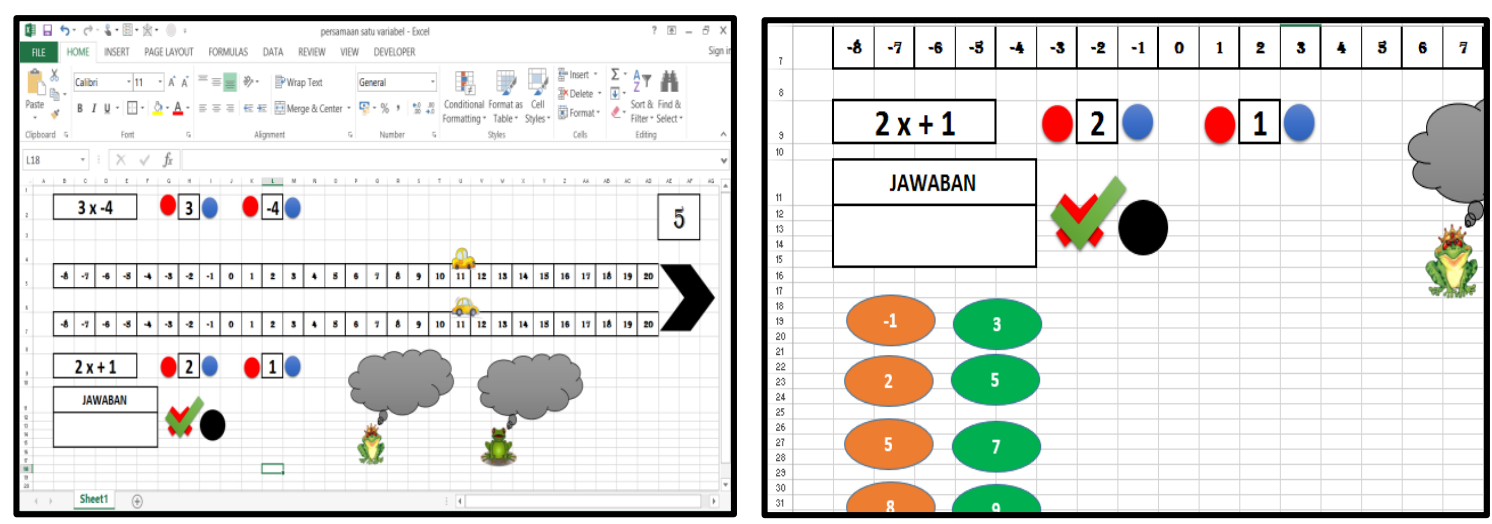

Figure 3. Designing a Picture of Math Game in Microsoft Excel The

Figure 3 depicts some figures which were designed according to the relation of the mathematical concept that is the equations of one variable. By making a story of the difference of the two-car journey that has the difference in speed and distance difference, and the time specified describes as answer x. And to move the car depends on the equation of each, while the two frogs as observers to see the difference in the distance of the initial car and the difference in the distance of the car as it begins to move as the reason for moving the variables and numbers from one segment to the other.Then the students answer the result of $\mathrm{x}$ whether same on the result of the answer when the car is moved, of all the commands, will be connected using the Visual Basic language.

After finishing to create a VBA-based math game for Microsoft Excel and then tested to students in the classroom, so students can deduce from some examples of questions related to the equation of one variable.
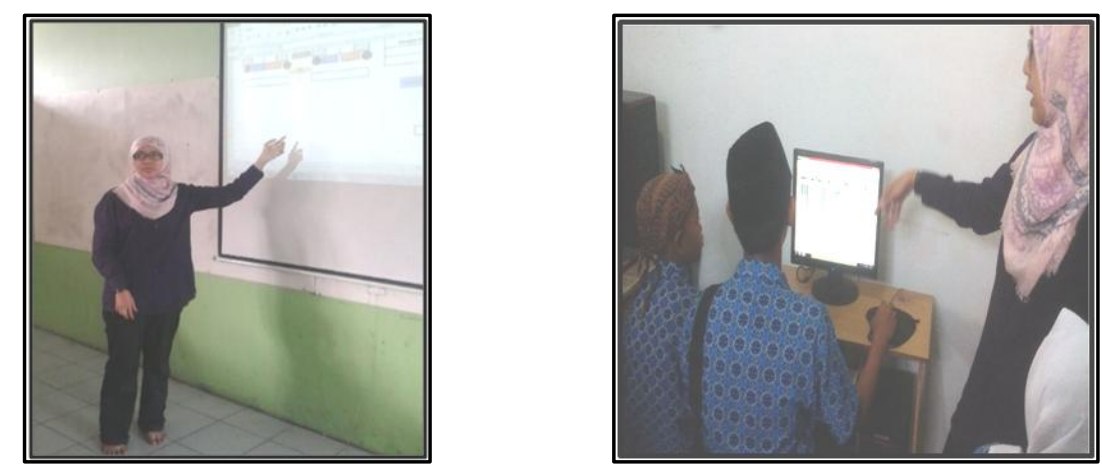

Figure 4. Students Practicing Gaming Media in Microsoft Excel

Students try from several examples of the equations of a mathematical variable then practiced from the properties of counting operations so that students can deduce from the process through the math game. 


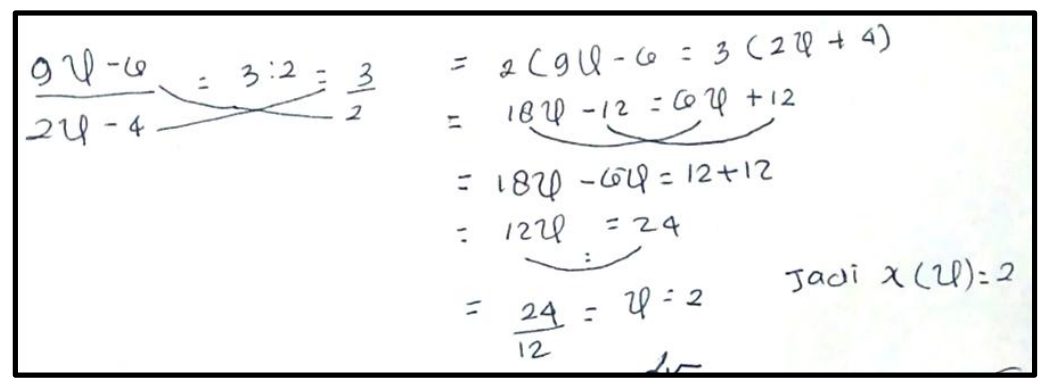

Figure 5. Students Understood About Equations One Variable

When given a question about the equation of one variable, students have understood the concept of addition properties and multiplication operations as what is depicted in Figure 5. So that they display the correct results. By providing math games, students tend to be more active in discussing with peers and actively giving opinions if there is a wrong and accurate calculation process. From the final results of the study, the work of 32 students. According to the mathematical calculation process of $6.78 \%$ miscalculation of students with the nature of distribution, $10.77 \%$ of students 'errors in the concept of comparison, $15.85 \%$ of the students' errors in calculating and operating calculations with property identity the opposite. And $25.37 \%$ of students have not been able to connect between images and mathematical concepts. It means that there is an increase in students 'abilities in students' understanding of the relationship of one variable. By using VBA-based ICT for Microsoft Excel, mathematics learning is more effective than learning without using VBA for Microsoft Excel, judging from the many activeness of students to solve mathematical questions. This is in line with Ghavifekr \& Rosdy (2015:188) which states that there is a factor of student activity Mathematical learning between teachers and students is more effective. In addition, it raises the confidence of students from working on the problem to solving the problem with the steps they make in accordance with the students' understanding ability in a structured manner after observing the method using VBA for Microsoft Excel, because there are positive attitudes students enjoy when displaying VBA games for Microsoft Excel and quickly responding when conducting discussions. This is in accordance with Cakir (2012:1021) that students' attitudes toward learning at school and at home have computers that have a good response compared to students who study without computers.

There are some aspects that must be considered by researchers to make teaching aids. First, the importance of good communication between teachers and students, because not all of them understand because of the explanation from VBA for Excel. Second, the teacher must make a strategy for making Vba for Microsoft Excel media before the learning and teaching process takes place because it considers the limitations of time with the weight of the material to be delivered.

\section{Conclusion}

Based on the results of research that VBA-based Math Games for Microsoft Excel can improve the ability of students to understand the junior high school and foster a sense of confidence students to work on the equation of one variable. By using mathematics learning media using VBA for Microsoft Excel, teachers can produce props more practical and efficient. As well as helping teachers to deliver interactive images relating to math materials at school. 


\section{Acknowledgment}

The authors want to express the gratitude to IKIP Siliwangi who had provided the place and time to do the research and funded from internal LP2M IKIP Siliwangi grant so that this research can go well. The authors also want to thank the math study program IKIP Siliwangi which gives a chance time to use the Laboratory of mathematics tools that can provide examples of math media to be applied in the VBA for Excel junior high school for Excel.

\section{Reference}

Astuti, D. (2018). Analisis Kemampuan Literasi Matematika Model Pembelajaran JUCAMA berpendekatan PMRI dengan Google Form sebagai Self Assessment, 1, 69-76.

Batubara, H. H. (2017). Pengembangan Media Pembelajaran Matematika berbasis Android untuk Siswa SD/MI. MUALLIMUNA: Jurnal Madrasah Ibtidaiyah, 3(1), $12-27$.

Bernard, M. (2014). Pengaruh Pembelajaran Dengan Menggunakan Multimedia Macromedia Falsh Terhadap Kemampuan Penalaran Matematik. Prosiding Seminar Nasional Pendidikan Matematika STKIP Siliwangi, 1, 425-429.

Bernard, M. (2015). Meningkatkan Kemampuan Komunikasi dan Penalaran Serta Disposisi Matematik Siswa SMK dengan Pendekatan Kontekstual Melalui Game Adobe Flash CS 4.0. Jurnal Ilmiah Program Studi Matematika STKIP Siliwangi Bandung, 4(2), 197-222.

Bernard, M., \& Chotimah, S. (2018). Improve student mathematical reasoning ability with open-ended approach using VBA for powerpoint. AIP Conference Proceedings, 020013. https://doi.org/10.1063/1.5054417

Cakir, O. (2012). Students' Self Confidence and Attitude Regarding Computer: An International Analysis Based on Computer Availability and Gender Factor. Procedia - Social and Behavioral Sciences, 47(1994), 1017-1022. https://doi.org/10.1016/j.sbspro.2012.06.772

Chotimah, S., Bernard, M., \& Wulandari, S. M. (2018). Contextual approach using VBA learning media to improve students ' mathematical displacement and disposition ability Contextual approach using VBA learning media to improve students ' mathematical displacement and disposition ability. Journal of Physics: Conference Series 948 012025. https://doi.org/10.1088/1742-6596/948/1/012025

Ghavifekr, S., \& Rosdy, W. A. W. (2015). Teaching and Learning with Technology: Effectiveness of ICT Integration in Schools Simin. International Journal of Research in Education and Science, 1(2), 175-191. https://doi.org/10.1111/j.13652729.2011.00453.x

Jarlskog, L. (2016). Survey of Adult Students with Mathematical Difficulties. Adults Learning Mathematics: An International Journal, 11(2), 41-51.

Njagi, M. W. (2015). LANGUAGE ISSUES ON MATHEMATICS ACHIEVEMENT Dr. Mercy Wanja Njagi, 3(6), 167-178.

S. Chamundeswari. (2014). Conceptual Errors Encountered in Mathematical Operations in Algebra among Students at the Secondary Level. International Journal of Innovative Science, Engineering \& Technology, 1(8), 24-38.

Senjayawati, E., \& Bernard, M. (2018). Penerapan Model Search - Solve - Create - Share untuk Mengembangkan Kemampuan Penalaran Berbantuan Sofware Geogebra 4.4. MAJU, 5(1), 66-78.

Sulaeman, A., Yusniawati, Y., Rohaeti, E. E., Padalarang, S., Perum, J., Bandung, K., ... Number, V. (2018). Meningkatkan Kemampuan Koneksi Matematis Siswa 
SMKdengan Menggunakan Pendekatan Berbasis Masalah Improving Mathematical Connection of Vocational High School Students Using the Problem Based Approach Improving Mathematical Connection of Vocational High Sch.

Uyanto, S. S. (2009). Pedoman Analisis Data dengan SPSS (3rd ed.). Yogyakarta: Graha Ilmu. Retrieved from Info@grahailmu.co.id

Wijayanti, N. A., \& Khikmiyah, F. (2016). Pada Materi Aritmatika Sosial di Kelas VII SMP. Didaktika, 22, 99-109. 